\title{
Performance Improvement of a Domestic Refrigerator Using Phase change Material (PCM)
}

\author{
Rezaur Rahman ${ }^{1}$, Adnan hasan ${ }^{2}$, Shubhra Kanti Das ${ }^{3}$, Md. Arafat Hossain ${ }^{4}$ \\ ${ }^{[1,2,3,4]}$ Department of Mechanical Engineering, Khulna University of Engineering \&Technology (KUET), \\ Khulna-9203, BANGLADESH
}

\begin{abstract}
The paper investigates the performance improvement provided by a phase change material $(P C M)$ associated with the evaporator in a domestic refrigerator. The heat release and storage rate of a refrigerator is depends upon the characteristics of refrigerant and its properties. The usage of phase change material (PCM) enhances the heat transfer rate thus improve the COP (Coefficient of performance) of refrigeration. The analysis of the experiment exemplifies the improvement of a conventional refrigeration system's COP (Coefficient of performance) considerably. Using water as PCM and for a certain thermal load it is found that the COP (Coefficient of performance) of the conventional refrigerator increased by $18-26 \%$ on average. Here the phase change material (PCM) used in a chamber built manually and which surrounds the Evaporator chamber of a conventional refrigerator. The whole heat transfer from load given to refrigerator cabinet to evaporator, evaporator to phase change material (PCM) by conduction. So the heat transfer rate of evaporator refrigerant increases remarkably which improves the COP (Coefficient of performance) the refrigeration system.
\end{abstract}

Keywords: COP, Evaporator, Phase Change Material, Refrigerator

\section{INTRODUCTION}

The most alarming environmental disorder namely "Global Warming" refers to the rising temperature of Earth's atmosphere and ocean and its projected continuation. The heat from the Sun is entrapped in the Earth and thus increases the temperature of the atmosphere by Greenhouse Effect. Refrigeration system is directly and invisibly responsible for Global Warming problem. For the typical home of the early 1990s, a frost-free refrigerator or freezer was the second most expensive home appliance to operate besides the water heater. Appliance makers were required to include labels listing an estimate of the annual cost of running each appliance so consumers could compare costs and energy usage.[1] A refrigerator (colloquially fridge) is a common household appliance that consists of a thermally insulated compartment and a heat pump (mechanical, electronic, or chemical) that transfers heat from the inside of the fridge to its external environment so that the inside of the fridge is cooled to a temperature below the ambient temperature of the room. [2] Domestic refrigerators are among the most energy demanding appliances in a household due to their continuous operation. [3] The domestic refrigerator is one found in almost all the homes for storing food, vegetables, fruits, beverages, and much more. [4] Materials that can store thermal energy reversible over a long time period are often referred to as latent heat storage materials. It also helped in heat transfer via conduction. [5]

\section{Objectives}

The objectives of the performance improvement of the domestic refrigerator by using the phase change material (PCM) are given below,

1. To fabricate the experimental set up by modifying the domestic refrigerator with PCM based refrigerator.

2. To observe the effects of phase change material (PCM) in compressor effect on COP.

3. To observe the difference on the Coefficient of performance (COP) of the refrigerator cycle with PCM and without PCM.

\section{Overview Of Phase Change Material (Pcm)}

PCMs latent heat storage can be achieved through solid-solid, solid-liquid, solid-gas and liquid-gas phase change. However, the only phase change used for PCMs is the solid-liquid change.

Thermal Energy Storage through Phase Change material has been used for wide applications in the field of air conditioning and refrigeration especially at industrial scale. [6]

A phase-change material (PCM) is a substance with a high heat of fusion which, melting and solidifying at a certain temperature, is capable of storing and releasing large amounts of energy. [7] 
Even though the thermal conductivity of phase change materials (PCM) is usually not high, it is sufficient to enhance the global heat transfer conditions of an evaporator with air as external fluid and natural convection as heat transfer mechanism. [8]

\section{Conventional Vapor Compression Refrigeration Cycle (Without Pcm)}

The vapor-compression uses a circulating liquid refrigerant as the medium which absorbs and removes heat from the space to be cooled and subsequently rejects that heat elsewhere. The main heat transfer part is done via convection method between evaporator coil and environment. Figure depicts a typical, singlestage vapor- compression system. All such systems have four components: a compressor, a condenser, a Thermal expansion valve (also called a throttle valve or Tx Valve), and an evaporator. Circulating refrigerant enters the compressor in the thermodynamic state known as a saturated vapor and is compressed to a higher pressure, resulting in a higher temperature as well. [9]

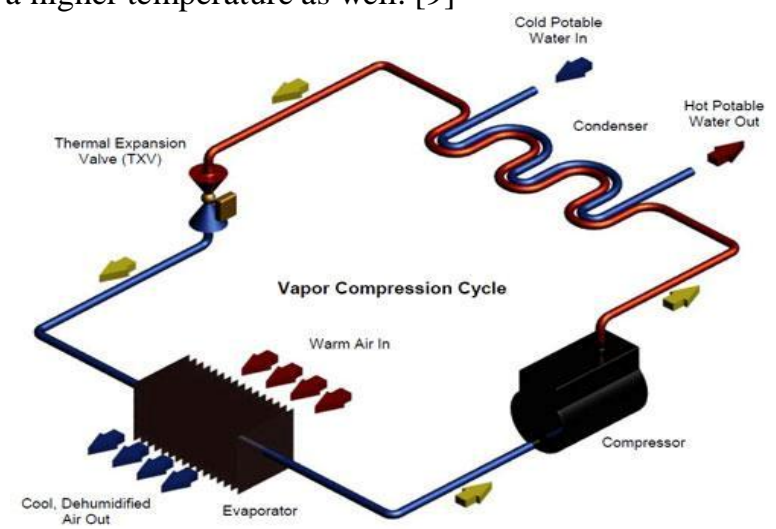

Fig 1: Conventional Vapor compression Refrigeration System

\section{Using Phase Change Material (PCM) as environment to release heat from evaporator}

In conventional system the heat releasing environment for evaporator is usually air but using a Phase Change Material (PCM) surrounding the evaporator coil work as a liquid or solid medium to release the heat. PCM is touched with the evaporator coil the stored heat energy of PCM will be extracted by the refrigerant through conduction method during compressor on mode. The conduction transfer is faster than the natural convection heat transfer. In the conventional refrigerator the cabinet heat is extracted by the refrigerant through natural convection. So the PCM will improve the heat transfer performance of the evaporator. A mathematical model of parallel plate's field with a phase change material that absorbs heat from the flow of warm moist air was developed and validated. In this study, effects of the design and the operating condition on the performance of the system are discussed only for the melting process and the interaction with the refrigeration system is not studied.[10]

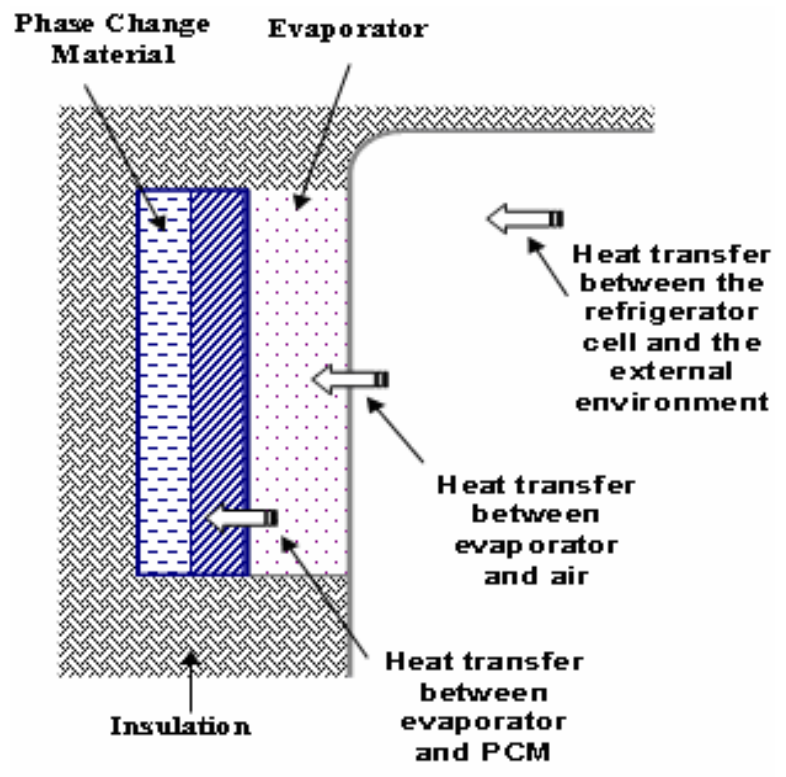

Fig 2: Heat Exchange between evaporator and phase change material 


\section{Development of Refrigeration System with a PCM box}

The liquid PCM passed through a coil or any path which surrounds the whole evaporator. The evaporator chamber is covered with another box which has the passage or storage cavity for PCM. When the compressor On-state is on action the liquid PCM releases the heat and become solid and the refrigerant takes the heat.

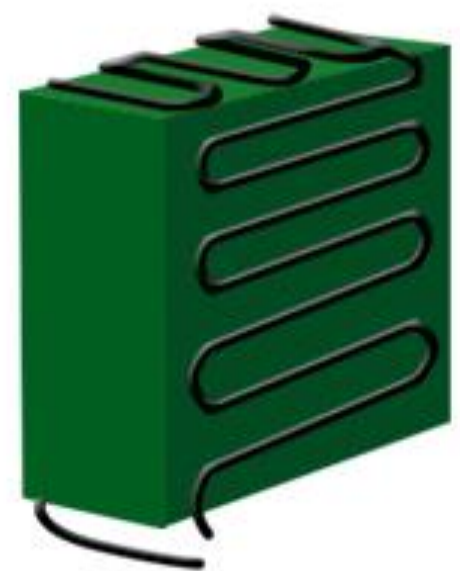

Step 1 Conventional Evaporator

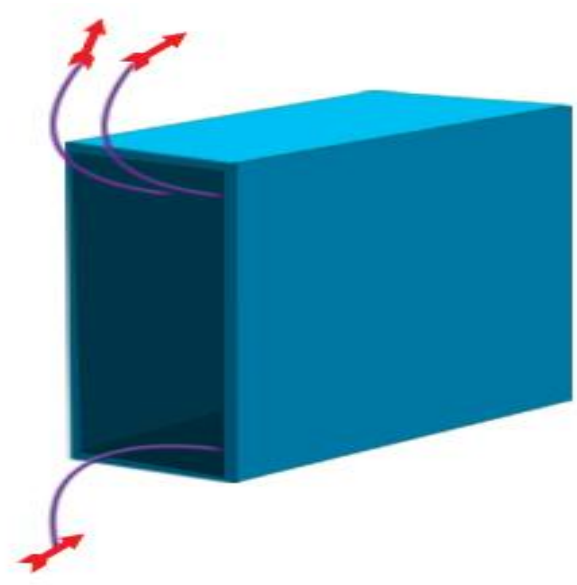

Step 2 PCM box with PCM passage

Fig 3: Evaporator and PCM box (to cover the evaporator and food cabinet).

\section{Experimental Setup}

A conventional household refrigerator is used in the modified form with PCM box located behind the evaporator cabinet to carry out the necessary experiments. It shows that the details of the location of the PCM box with the evaporator cabinet. The PCM box is made up by aluminum sheet, which is fourteen inch width, 12 inch height and one inch depth. The evaporator cabinet box of outer volume $0.025 \mathrm{~m}^{3}$ with cooling coil is inserted into the empty PCM box of internal volume $.001 \mathrm{~m} 3$. The thickness of the annular space between PCM box and evaporator cabinet is one inch. In the top of the PCM box there are four holes of half inch diameter each to charge the PCM into the box. In the bottom of the PCM box there are four holes of half inch diameter each to charge the PCM into the box. The experimental set up comprised with a refrigerator, pressure gauge, thermocouple, phase change material box. The followings are the major technical specifications of the refrigerator.

1. Cabinet:

-Internal volume $=0.015$ cubic meter

2. Evaporator:

-Mode of heat transfer= Free convection and conduction.

-Linear length of coil or tube $=14.5$ feet $=4.4$ meter

-Internal and external diameter of the tube $=5 \mathrm{~mm}$ and $6 \mathrm{~mm}$ or $0.00525 \mathrm{~m}$ and $0.00635 \mathrm{~m}$ respectively.

-Material of coil or tube $=$ copper tube.

3. Condenser:

- Mode of heat transfer= Free convection

- Linear length of the coil $=4.1 \mathrm{~m}$

-Internal and external diameter of the tube $=3.23 \mathrm{~mm}$ and $4.23 \mathrm{~mm}$ or $0.003 \mathrm{~m}$ and $0.004 \mathrm{~m}$ respectively.

- Material of the tube $=$ steel and wire tube.

4. Compressor:

LG MA 42LFJG 1PH 220-240V, 50HZ

5. Expansion device $=$ Capillary tube

6. On/Off control and self-defrost.

7. Refrigerant $=1,1,1,2$-Tetrafluoroethane (R-134a)

Table 1: Physical Properties of HCF- 134a refrigerant

\begin{tabular}{|l|l|}
\hline Boiling point at $1 \mathrm{~atm}(101.3 \mathrm{kpa}$ or 1.013bar) & $-26.3^{\circ} \mathrm{C}$ \\
\hline Freezing point & $-103.3^{\circ} \mathrm{C}$ \\
\hline Critical temperature & $101.1^{0} \mathrm{C}$ \\
\hline Critical pressure & $4060 \mathrm{kPa}$ \\
\hline Critical volume & $1.94 \times 10^{-3} \mathrm{~m}^{3} / \mathrm{kg}$ \\
\hline Critical density & $515.3 \mathrm{~kg} / \mathrm{m}^{3}$ \\
\hline Density(liquid at $\left.25^{\circ} \mathrm{C}\right)$ & $1206 \mathrm{~kg} / \mathrm{m}^{3}$ \\
\hline
\end{tabular}




\begin{tabular}{|l|l|}
\hline Density(Saturated vapor) at boiling point & $5.25 \mathrm{~kg} / \mathrm{m}^{3}$ \\
\hline Heat capacity(liquid) at $25^{\circ} \mathrm{C}$ & $0.339 \mathrm{kcal} / \mathrm{kg} . \mathrm{K}$ \\
\hline Heat capacity at $25^{\circ} \mathrm{C}$ and $1 \mathrm{~atm}$ & $0.204 \mathrm{kcal} / \mathrm{kg} . \mathrm{K}$ \\
\hline
\end{tabular}

Table 2 Uncertainties of Measurement

\begin{tabular}{|l|l|l|}
\hline Measured Parameter & Measuring Device & Uncertainty \\
\hline Temperature & Thermocouples & $\pm 2.75 \%$ \\
\hline Pressure & Pressure Gauge & $\pm 0.01 \mathrm{psi}$ \\
\hline
\end{tabular}

Table 3 Experimental ranges and conditions

\begin{tabular}{|l|l|l|l|l|}
\hline Types of PCM & $\begin{array}{l}\text { Quantity of PCM } \\
\text { (liter) }\end{array}$ & Test time (min) & Ambient Temp. ${ }^{\circ} \mathrm{C}$ & $\begin{array}{l}\text { Cabinet setting Temp. } \\
{ }^{\circ} \mathrm{C}\end{array}$ \\
\hline Without PCM & --------------- & 150 & $30-31$ & -5 \\
\hline Water & 4.5 & 150 & $30-31$ & -5 \\
\hline
\end{tabular}

VIII. Data Collection And Calculation

The following data have been collected for each test run at the steady state condition of the system.

1. $\quad \mathrm{P}_{1}=$ Compressor suction/Evaporator outlet pressure(bar)

2. $\mathrm{P}_{3}=$ Evaporator Inlet Pressure(bar)

3. $\quad \mathrm{T}_{1}=$ Compressor suction Temperature $\left({ }^{\circ} \mathrm{C}\right)$

4. $\quad \mathrm{T}_{2}=$ Compressor discharge/condenser Inlet Temperature $\left({ }^{\circ} \mathrm{C}\right)$

5. $\quad \mathrm{T}_{3}=$ Condenser Outlet Temperature $\left({ }^{\circ} \mathrm{C}\right)$

6. $\quad \mathrm{T}_{4}=$ Evaporator Inlet Temperature $\left({ }^{\circ} \mathrm{C}\right)$

7. $\mathrm{t}=$ Time

Table 4 Experimental Data without Phase Change Material (PCM)

\begin{tabular}{|c|c|c|c|c|c|c|}
\hline $\begin{array}{l}\text { Time } \\
\text { Reading } \\
\text { taken }\end{array}$ & $\begin{array}{l}\text { Evaporator } \\
\text { inlet Pressure } \\
\mathrm{P}_{1} \text { bar }\end{array}$ & $\begin{array}{l}\text { Condenser } \\
\text { outlet Pressure } \\
\mathrm{P}_{3} \text { bar }\end{array}$ & $\begin{array}{l}\text { Compressor inlet } \\
\text { Temp } \\
\mathrm{T}_{1}{ }^{\circ} \mathrm{C}\end{array}$ & $\begin{array}{l}\text { Compressor } \\
\text { outlet Temp } \\
\mathrm{T}_{2}{ }^{\circ} \mathrm{C}\end{array}$ & $\begin{array}{l}\text { Condenser } \\
\text { inlet Temp } \\
\mathrm{T}_{3}{ }^{\circ} \mathrm{C}\end{array}$ & $\begin{array}{l}\text { Condenser outlet } \\
\text { Temp } \\
\mathrm{T}_{4}{ }^{\circ} \mathrm{C}\end{array}$ \\
\hline $\begin{array}{l}11.10 \\
\text { am }\end{array}$ & 0.27 & 9 & 26 & 50 & 33 & 17 \\
\hline $\begin{array}{l}11.25 \\
\mathrm{am}\end{array}$ & 0.40 & 8.5 & 27 & 53 & 36 & 17 \\
\hline $\begin{array}{l}11.40 \\
\text { am }\end{array}$ & 0.44 & 9 & 26 & 58 & 37 & 19 \\
\hline $\begin{array}{l}11.55 \\
\mathrm{am}\end{array}$ & 0.47 & 9.5 & 27 & 61 & 37 & 18 \\
\hline $\begin{array}{l}12.10 \\
\mathrm{pm}\end{array}$ & 0.51 & 10 & 27 & 65 & 39 & 21 \\
\hline $\begin{array}{l}12.25 \\
\mathrm{pm}\end{array}$ & 0.34 & 10.2 & 26 & 67 & 38 & 19 \\
\hline $\begin{array}{l}12.40 \\
\mathrm{pm}\end{array}$ & 0.44 & 10.2 & 22 & 72 & 41 & 18 \\
\hline $\begin{array}{l}12.55 p \\
m\end{array}$ & 0.44 & 10.2 & 22 & 72 & 39 & 18 \\
\hline $1.10 \mathrm{pm}$ & 0.57 & 10.4 & 20 & 72 & 41 & 19 \\
\hline $\begin{array}{l}1.25 \\
\mathrm{pm}\end{array}$ & 0.57 & 10.6 & 20 & 72 & 42 & 19 \\
\hline
\end{tabular}

Table 5: COP found in each test run without Phase Change Material (PCM)

\begin{tabular}{|l|l|}
\hline Number of observation & COP found in Vapor compression Refrigerator Without PCM \\
\hline 1 & 6.12 \\
\hline 2 & 5.55 \\
\hline 3 & 6.12 \\
\hline 4 & 5.50 \\
\hline 5 & 5.13 \\
\hline 6 & 6.78 \\
\hline 7 & 5.10 \\
\hline 8 & 5.11 \\
\hline 9 & 5.02 \\
\hline 10 & 5.02 \\
\hline
\end{tabular}


Table 6 Experimental Data with Phase Change Material (PCM)

\begin{tabular}{|c|c|c|c|c|c|c|}
\hline $\begin{array}{l}\text { Time } \\
\text { Reading } \\
\text { taken }\end{array}$ & $\begin{array}{l}\text { Evaporator } \\
\text { inlet Pressure } \\
\mathrm{P}_{1} \text { bar }\end{array}$ & $\begin{array}{l}\text { Condenser } \\
\text { outlet Pressure } \\
\mathrm{P}_{3} \text { bar }\end{array}$ & $\begin{array}{l}\text { Compressor inlet } \\
\text { Temp } \\
\mathrm{T}_{1}{ }^{\circ} \mathrm{C}\end{array}$ & $\begin{array}{l}\text { Compressor } \\
\text { outlet Temp } \\
\mathrm{T}_{2}{ }^{\circ} \mathrm{C}\end{array}$ & $\begin{array}{l}\text { Condenser } \\
\text { inlet Temp } \\
\mathrm{T}_{3}{ }^{\circ} \mathrm{C} \\
\end{array}$ & $\begin{array}{l}\text { Condenser } \\
\text { Temp } \\
\mathrm{T}_{4}{ }^{\circ} \mathrm{C}\end{array}$ \\
\hline $10.00 \mathrm{am}$ & 0.44 & 11 & 30 & 56 & 48 & 22 \\
\hline $10.15 \mathrm{am}$ & 0.61 & 11.5 & 31 & 59 & 49 & 23 \\
\hline $10.30 \mathrm{am}$ & 0.68 & 12.4 & 33 & 63 & 53 & 25 \\
\hline $10.45 \mathrm{am}$ & 0.78 & 12.8 & 34 & 65 & 58 & 27 \\
\hline $11.00 \mathrm{am}$ & 0.98 & 14 & 35 & 68 & 59 & 30 \\
\hline $11.15 \mathrm{am}$ & 1.02 & 15.5 & 35 & 70 & 57 & 32 \\
\hline $11.30 \mathrm{am}$ & 1.02 & 15.5 & 35 & 73 & 58 & 33 \\
\hline $11.45 \mathrm{am}$ & 1.02 & 15.5 & 35 & 75 & 62 & 33 \\
\hline $12.00 \mathrm{Pm}$ & 1.09 & 16 & 34 & 77 & 62 & 32 \\
\hline 12.15 & 1.09 & 16 & 34 & 77 & 61 & 32 \\
\hline
\end{tabular}

Table 7 COP found in each test run with Phase Change Material (PCM)

\begin{tabular}{|l|l|}
\hline Number of observation & COP found in Vapor compression Refrigerator With PCM \\
\hline 1 & 9.85 \\
\hline 2 & 9.42 \\
\hline 3 & 9.45 \\
\hline 4 & 9.04 \\
\hline 5 & 9.00 \\
\hline 6 & 9.00 \\
\hline 7 & 9.00 \\
\hline 9 & 8.91 \\
\hline 10 & 8.82 \\
\hline
\end{tabular}

Below the calculation of COP is given with proper calculation the corresponding enthalpy for desire pressure and temperature found using P-h diagram of refrigerant R-134a.

At step 1:

$\mathrm{COP}_{\text {WITHOUT PCM }}=\frac{h 1-h 4}{h 2-h 1}[9]=\frac{410-230}{445-410}=5.78$

$\mathrm{COP}_{\text {WITH PCM }}=\frac{h 1-h 4}{h 2-h 1}=\frac{435-232}{455-435}=7.27$

Percentage of COP improved for the use of Phase Change Material (PCM)

$=\frac{7.27-5.78}{5.78} \times 100 \%=25.78 \%$

At step 2:

$\mathrm{COP}_{\text {WITHOUT PCM }}=\frac{h 1-h 4}{h 2-h 1}=\frac{420-220}{456-420}=5.85$

$\mathrm{COP}_{\text {WITH PCM }}=\frac{h 1-h 4}{h 2-h 1}=\frac{430-232}{451-430}=7.17$

Percentage of COP improved for the use of Phase Change Material (PCM)

$$
=\frac{7.17-5.85}{5.85} \times 100 \%=22.56 \%
$$

At step 3:

$\mathrm{COP}_{\text {WITHOUT PCM }}=\frac{h 1-h 4}{h 2-h 1}=\frac{422-226}{454-422}=5.88$

$\mathrm{COP}_{\text {WITH PCM }}=\frac{h 1-h 4}{h 2-h 1}=\frac{433-232}{433-453}=7.18$

Percentage of COP improved for the use of Phase Change Material (PCM)

$=\frac{7.18-5.88}{5.88} \times 100 \%=22.25 \%$

At step 4:

$\mathrm{COP}_{\text {WITHOUT PCM }}=\frac{h 1-h 4}{h 2-h 1}=\frac{425-218}{462-425}=5.5$ 
$\mathrm{COP}_{\mathrm{WITH} \mathrm{PCM}}=\frac{h 1-h 4}{h 2-h 1}=\frac{434-235}{456-434}=6.70$

Percentage of COP improved for the use of Phase Change Material (PCM)

$=\frac{6.70-5.5}{5.5} \times 100 \%=21.85 \%$

At step 5:

$\mathrm{COP}_{\text {WITHOUT PCM }}=\frac{h 1-h 4}{h 2-h 1}=\frac{427-232}{465-427}=5.65$

$\mathrm{COP}_{\mathrm{WITH} \mathrm{PCM}}=\frac{h 1-h 4}{h 2-h 1}=\frac{434-236}{456-434}=6.69$

Percentage of COP improved for the use of Phase Change Material (PCM) $=\frac{6.69-5.65}{5.65} \times 100 \%=18.57 \%$

At step 6:

$\mathrm{COP}_{\text {WITHOUT PCM }}=\frac{h 1-h 4}{h 2-h 1}=\frac{430-240}{458-430}=6.78$

$\mathrm{COP}_{\text {WITH PCM }}=\frac{h 1-h 4}{h 2-h 1}=\frac{436-238}{458-436}=8.102$

Percentage of COP improved for the use of Phase Change Material (PCM) $=\frac{8.102-6.78}{6.78} \times 100 \%=19.5 \%$

At step 7:

$\mathrm{COP}_{\text {WITHOUT PCM }}=\frac{h 1-h 4}{h 2-h 1}=\frac{420-226}{458-420}=6.45$

$\mathrm{COP}_{\text {WITH PCM }}=\frac{h 1-h 4}{h 2-h 1}=\frac{438-240}{460-438}=7.76$

Percentage of COP improved for the use of Phase Change Material (PCM) $=\frac{7.76-6.45}{6.45} \times 100 \%=20.37 \%$

At step 8:

$\mathrm{COP}_{\text {WITHOUT PCM }}=\frac{h 1-h 4}{h 2-h 1}=\frac{427-232}{466-427}=6.55$

$\mathrm{COP}_{\mathrm{WITH} \mathrm{PCM}}=\frac{h 1-h 4}{h 2-h 1}=\frac{438-242}{460-438}=7.956$

Percentage of COP improved for the use of Phase Change Material (PCM) $=\frac{7.96-6.55}{6.55} \times 100 \%=21.47 \%$

At step 9:

$\mathrm{COP}_{\text {WITHOUT PCM }}=\frac{h 1-h 4}{h 2-h 1}=\frac{426-225}{466-426}=5.82$

$\mathrm{COP}_{\text {WITH PCM }}=\frac{h 1-h 4}{h 2-h 1}=\frac{438-244}{460-438}=7.08$

Percentage of COP improved for the use of Phase Change Material (PCM) $=\frac{7.08-5.82}{5.82} \times 100 \%=21.69 \%$

At step 10:

$\mathrm{COP}_{\text {WITHOUT PCM }}=\frac{h 1-h 4}{h 2-h 1}=\frac{426-225}{466-426}=5.94$

$\mathrm{COP}_{\mathrm{WITH} \mathrm{PCM}}=\frac{h 1-h 4}{h 2-h 1}=\frac{442-246}{464-442}=7.21$

Percentage of COP improved for the use of Phase Change Material (PCM) $=\frac{7.21-5.94}{5.94} \times 100 \%=21.49 \%$ 
IX. Few Photographs Of Actual Experimental Setup

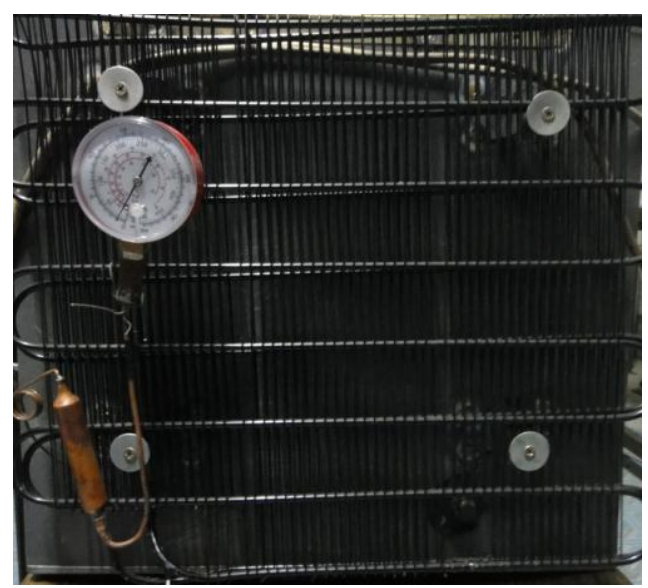

Fig 4 High pressure gauge fitted in the outlet of the Compressor.

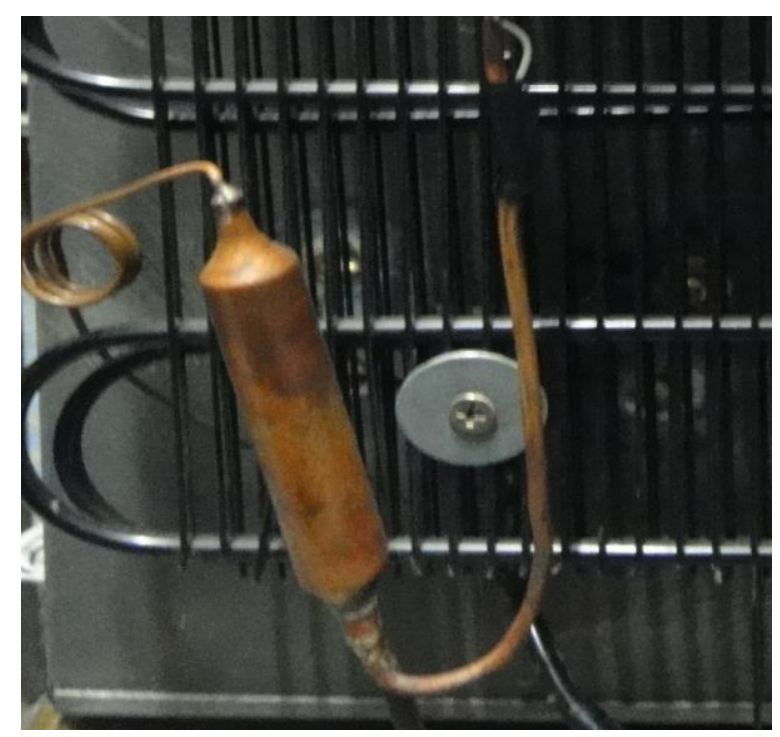

Fig 5 Filter fitted with an Expansion valve.

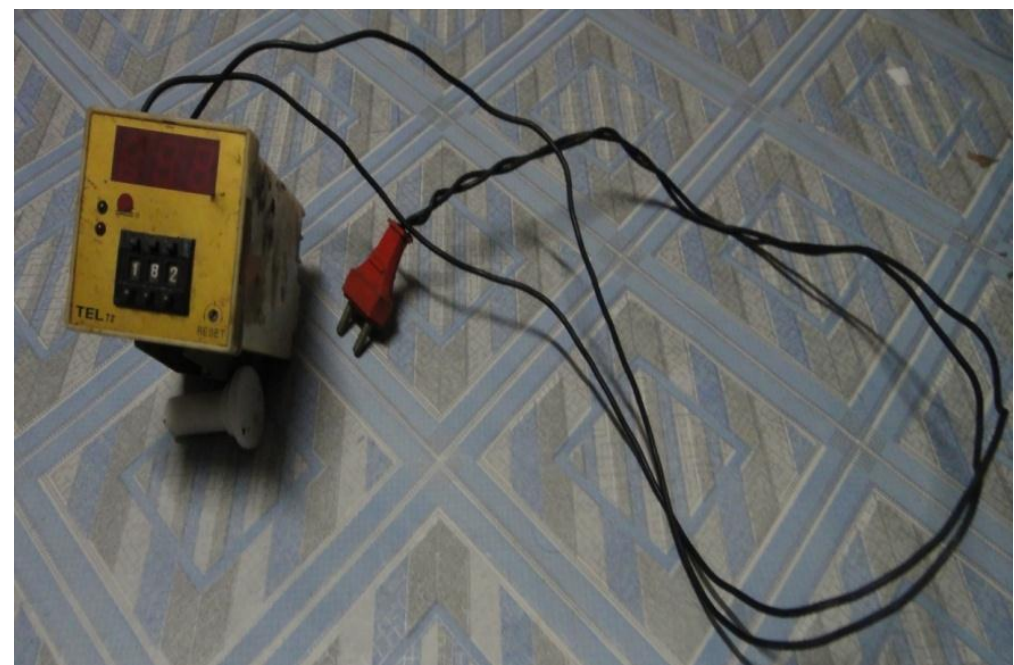

Fig 6 Digital Temperature display. 


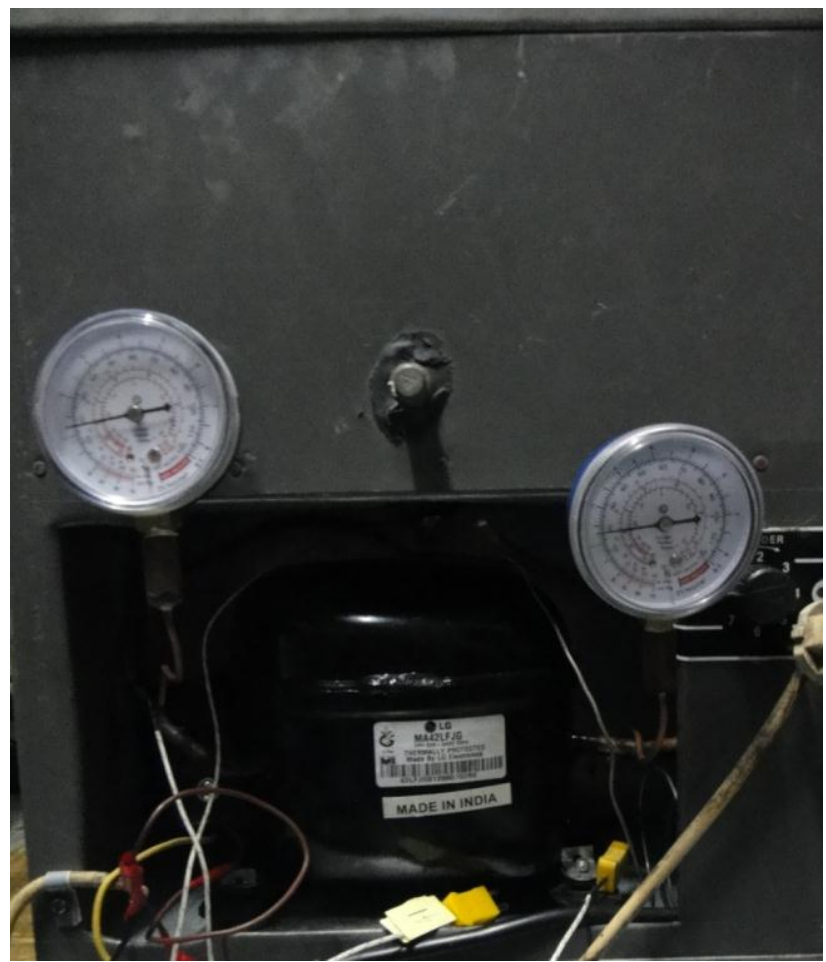

Fig. 7 Low pressure gauge fitted in the inlet and outlet of Evaporator.

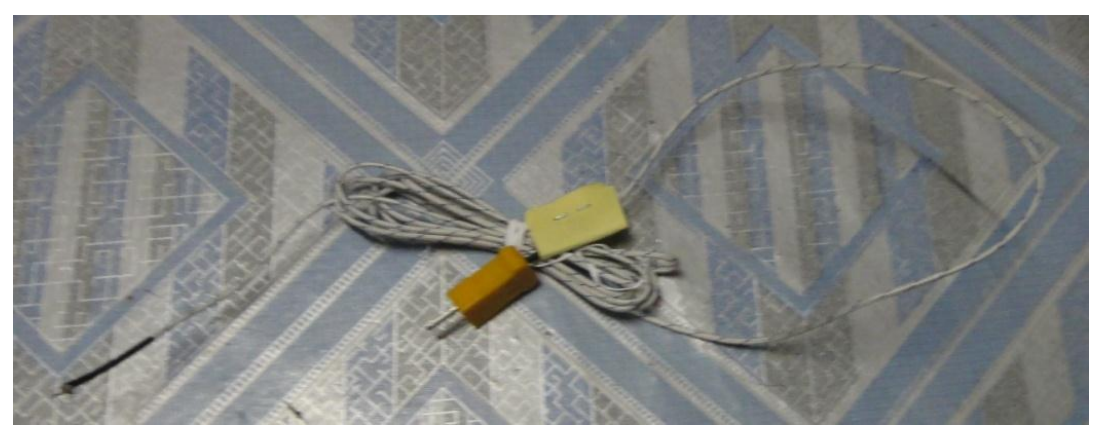

Fig 8 K-type thermocouple probe.

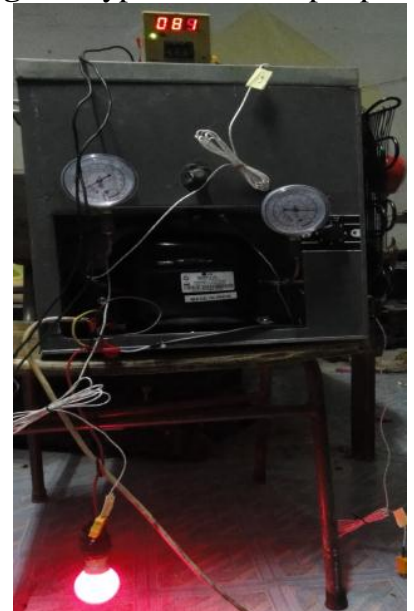

Fig 9 Refrigeration system during the experiment.

\section{Future Plan}

As we know for Phase Change Material heat is absorbed or released when the material changes from solid to liquid and vice versa; thus, PCMs are classified as latent heat storage (LHS) units. If PCM is used in the cabinet then it will take most of the heat by changing its phase from solid to liquid. The temperature is constant until the melting process in finished. The heat stored during the phase change process (melting process) of the 
material is called latent heat as shown in Fig 10. Thus for a particular period of time (until the PCM melts completely) the desired temperature of the product can be maintained during the off cycle of the compressor which ultimately prolonged the off cycle. So it will decrease the per month energy consumption by a refrigerator. So main plan will be to measure the power consumption per month using phase change material and measure the power saved by it.

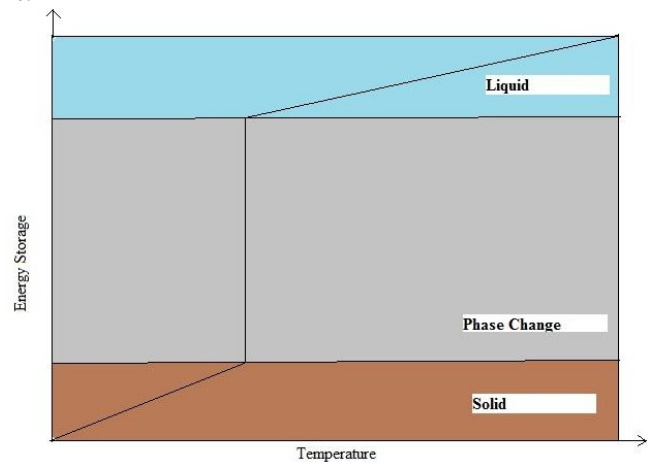

Fig 10 Phase change diagram with energy storage of a phase change material

\section{CONCLUSION}

Use of water as PCM imposes a great impact on COP improvement at certain thermal loads. Using water as PCM and certain thermal load it is found that the 18-26\% COP improvement has been achieved by the PCM in respect without PCM in conventional refrigerator. Experiment tests have been carried out to investigate the performance improvement of a household refrigerator using two different phase change materials of different quantities at different loads. Depending on the PCM and the thermal load around $18-26 \%$ COP improvement has been achieved by the PCM in respect to without PCM.

\section{Acknowledgments}

The completion of this thesis marks the end of a tough rugged, but very rewarding event in my life. Fortunately I was embraced by a number of important and some instances pivotal people in this event.

First of all, I'd like to express my gratitude to my thesis supervisor, Dr. Md. Nawsher Ali Moral, Professor, Department of Mechanical Engineering, Khulna University of Engineering and Technology, Khulna. It was my privilege to work with him, who completely showed me what and extraordinary should be like. Without his help, support and courage it'd be difficult for me to achieve this milestone. I'd also like to express my sincere gratitude to Dr. Mohammad Mashud Professor and Head, Department of Mechanical Engineering. For his persuasion, invaluable advice and proceeding the departmental facilities and financial support to carry out the experiment. My special thanks to Associate Prof. Dr Mohammad Ariful Islam, of the same university for making a helpful suggestion regarding the construction of whole experimental setup. During this experiment special thanks to Mohammad Ilias Inam, Assistant Professor, Department of Mechanical Engineering in the same university. Thanks a due to the faculty members and stuff of the department of Mechanical Engineering for their constant support and help.

\section{REFERENCES}

[1] "The Advent of Mechanical Refrigeration Alters Daily Life and National Economies Throughout the World - Science and Its Times: 1800-1899". Retrieved 2007-05-20.

[2] Internet Source-http://en.wikipedia.org/wiki/Refrigerator

[3] MARQUES, C., D A V I E S , G., MAIDMENT, G., EVANS, J. A. "application of phase change materials to domestic refrigerators." 9th International Conference onPhase-Change Materials and Slurries for Refrigeration and Air Conditioning, 2010

[4] Internet Source- http://www.brighthubengineering.com/hvac/66729- domestic- refrigerator-parts-and-their-working/

[5] Internet Source- http://www.iolitec.de/en/Heat-Storage-Heat- Transport/phase-changing-materials.html

[6] Tulapurkar, Chetan. "Phase change materials for domestic refrigerators to improve food quality and prolong compressor of time." International refrigeration and air conditioning conference. 2010

[7] Internet Source-http://en.wikipedia.org/wiki/Phase_change_material

[8] Azzouz, K. Leducq, D. Guilpart, J. Gobin, D. "Improving the energy efficiency of a vapor compression system using a phase change material" Second Conference on Phase Change Material \& Slurry : Scientific Conference \& Business Forum. 15 17 June 2005 Yverdon-les-Bains, Switzerland.

[9] Perry, R.H. and Green, D.W. (1984). Perry's Chemical Engineers' Handbook (6th Edition ed.). McGraw Hill, Inc.. ISBN ISBN 007-049479-7. (see pages 12-27 through 12-38)

[10] Simard A.P., Lacroix M., (2003), Study of the thermal behavior of a latent heat cold storage unit operating under frosting condition. Energy convers. Manag. 44, 1605-1624. 